\title{
The changes of Inducible Nitric Oxide Synthase, Endothelial Nitric Oxide Synthase and Cyclooxygenase-2 mRNA expressions in intrauterine tissues of pregnant rats
}

\author{
Elvan ANADOL ${ }^{1}$, Atiye Seda YAR $^{2}$, Sevda MENEVŞE ${ }^{2}$ \\ ${ }^{1}$ Gazi University, Laboratory Animals Breeding and Experimental Research Center, Ankara; ${ }^{2}$ Gazi University, Faculty of Medicine, \\ Department of Medical Biology and Genetics, Ankara / Turkey.
}

\begin{abstract}
Summary: Prostaglandins (PGs) are produced by the intrauterine tissues of pregnancy and play important role in all of the physiological processes of parturition. PGs are synthesized from arachidonic acid by the action of cyclooxygenase (COX). Nitric oxide (NO) is a potent smooth muscle relaxant and is considered to be an important local mediator that suppresses uterine contractility. There may be an interaction between the NO and PG pathways in regulating the nitric oxide synthase (NOS) and COX expression and this interaction may play a critical role in the control of cervical ripening and parturition. The purpose of this study is to examine the expression of cyclooxygenase-2 (COX-2), inducible NOS (iNOS) and endothelial NOS (eNOS) mRNA levels during gestation, parturition, and postpartum in pregnant rat uterus. Forty-two pregnant Sprague Dawley rats were randomly divided into 7 groups. Both uterine horns were removed and the pups and placentas were discarded. Complementary DNA (cDNA) was synthesized after isolation of total RNA from the tissues. The relative expression of iNOS, eNOS and COX-2 genes were measured by quantitative real-time polymerase chain reaction (QRT-PCR). The mRNA level of iNOS was increased during gestation; highest level in parturition and then it decreased at postpartum. The eNOS mRNA level was generally low during gestation in all groups and was significantly increased at postpartum. The COX-2 mRNA levels decreased as the pregnancy progressed to term with the highest level occurring on day 21 and the lovest levels during the postpartum period. In conclusion, there may be an interaction between the NO and PG pathways in cervical ripening and parturition. These results may show that mRNA levels of eNOS, iNOS and COX-2 genes may be effective cervical ripening during pregnancy and parturition.
\end{abstract}

Key words: cyclooxygenase-2, gestation, intrauterine tissue, nitric oxide synthase, parturition.

\section{Gebe ratların rahim içi dokularında Uyarılabilir Nitrik Oksit Sentaz, Endotelyal Nitrik Oksit Sentaz ve Siklooksijenaz-2 mRNA ekspresyon değişiklikleri}

Özet: Prostaglandinler (PG) gebelikte rahim içi dokularda üretilirler ve doğum sırasındaki tüm fizyolojik süreçlerde önemli rol oynarlar. PG'ler araşidonik asitten siklooksijenaz (COX) enziminin aktivitesi ile sentezlenirler. Nitrik oksit (NO) güçlü bir düz kas gevşetici ve uterus kasılmasını baskılayan önemli bir bölgesel ara bulucu olarak kabul edilir. Nitrik oksit sentaz (NOS) ve COX ifadelenmesinin düzenlenmesinde NO ve PG yolakları arasında bir etkileşim olabilir ve bu etkileşim servikal olgunlaşma ve doğumun kontrolünde kritik bir rol oynayabilir. Bu çalışmanın amacı, hamile rat uterusunda gebelikte, doğum sırasında ve doğum sonrasında siklooksijenaz-2 (COX-2), uyarılabilir NOS (iNOS) ve endotelyal NOS (eNOS) mRNA düzeylerini incelemektir. Kırk iki hamile Sprague Dawley rat rastgele olarak 7 gruba ayrıldı. Her iki uterin boynuzu ve yavrular ve plasenta çıkarıldı. Tamamlayıcı DNA (cDNA) dokulardan total RNA izole edildikten sonra sentezlendi. iNOS, eNOS ve COX-2 genlerinin göreceli ifadelenmesi kantitatif gerçek zamanlı polimeraz zincir reaksiyonu (QRT-PCR) ile ölçüldü. iNOS mRNA düzeyleri gebelik sırasında arttı, doğum sırasında en yüksek düzeye çıktı ve doğum sonrasında azaldı. eNOS mRNA düzeyleri tüm gruplarda gebelik boyunca genel olarak düşüktü ve doğum sonrasında belirgin bir şekilde yükseldi. COX-2 mRNA düzeyleri gebeliğin sonlarına doğru azaldı, gebeliğin 21 . gününde en yüksek seviyeye ulaştı ve doğum sonrası dönemde en düşük düzeylerde kaldı. Sonuç olarak servikal genişleme ve doğum sırasında, NO ve PG yolakları arasında bir etkileşim olabilir. Bu sonuçlar eNOS, iNOS ve COX-2 genlerinin mRNA düzeylerindeki değişikliklerin gebelikte servikal olgunlaşma ve doğum sırasında etkili olabileceğini gösterebilir.

Anahtar sözcükler: doğum, gebelik, intrauterine doku, nitric oksit sentaz, siklooksijenaz-2.

\section{Introduction}

The pregnant uterus is thought to be a passive organ, quiescent until receiving a contractile stimulus. Influences that maintain quiescence might be present throughout gestation to prevent contractions of the growing uterus (1). Synthesis and metabolism of uterine Prostaglandins (PGs) are important in the regulation of uterine activity and they participate in the process of the estrous cycle, ovulation, processes of pregnancy and in parturition. PGs are produced by the intrauterine tissues 
during pregnancy and play important roles in all of the physiological progression of parturition $(1,16)$. PGs have an influence on both endometrium and myometrium (29). Although the mechanisms that lead to the initiation of uterine contractions are not entirely understood, it is clear that prostaglandins play a key role in the initiation of myometrial activity in pregnancy and parturition (20).

Cyclooxygenase (COX) enzymes are major components of the PG synthesis pathway. The activities of COX represent a rate-limiting step in the formation of PGs from arachidonic acid (22). Two isoforms of COX have been identified: COX-1 and COX-2 $(22,23)$. COX1 is constitutively expressed in most tissues with constant prostaglandin synthesis and is considered as a housekeeping gene (23), although more recent evidence shows regulated expression in both the inflammatory and reproductive systems (11). COX-2, on the other hand, is an inducible enzyme activated by a wide range of ligands and is associated with inflammation $(11,23)$. COX-2 upregulation is more strongly associated with the onset of parturition in humans (31). Arslan and Zingg previously showed that COX-2 mRNA levels were significantly increased from day 7 of rat pregnancy till parturition in the rat uterine tissues (3). Furthermore, Dong et al. found an increase in COX-2 expressions of protein levels in laboring rat uterine tissue (7).

Nitric oxide (NO) is a major mediator that suppresses uterine contractility during pregnancy until term. NO is synthesized from NO synthases (NOSs), which is a family of isoenzymes that convert L-arginine to L-citrulline and NO (13). Three NOS isoforms have been identified, neuronal NOS (nNOS), inducible NOS (iNOS) and endothelial NOS (eNOS) (17). eNOS and nNOS are constitutive enzymes, $\mathrm{Ca}^{+2}$ and calmodulin dependent, and they play a role in the maintenance of vascular tone, antiplatelet aggregation, vasodilatation and neurotransmission, respectively $(13,17)$. In contrast, iNOS, an inflammation-inducible $\mathrm{Ca}^{+2}$ independent enzyme, can be induced by various cytokines and is present in many cell types. eNOS and nNOS release small amounts of NO, while iNOS synthesizes large quantities of $\mathrm{NO}$ for a long period of time $(13,17)$. It has been demonstrated that a decrease in NOS activity occurs in uterine tissues of rats (18) and rabbits (21) at term. Furthermore, the NOS protein content in the uterus is increased during pregnancy and decreased at term (8), suggesting that changes in NOS enzyme content and thus NO production may be involved in the maintenance of uterine quiescence during pregnancy and increased uterine activity at term. Moreover, three NOS isoforms (iNOS, eNOS and nNOS) have been identified in placental tissue (10). Several studies suggest that there may be an interaction between NO and PG pathways in regulating the NOS and COX expression and this interaction may play a critical role in the control of cervical ripening and parturition $(25,30)$. In addition, it has been shown that during pregnancy in both the rat and human, the endometrium expresses the enzyme iNOS, which produces nitric oxide, a smooth muscle relaxant $(4,19)$.

COX-2, iNOS and eNOS have been suggested as the key mediators of initiation and progression of parturition $(3-7,14,15)$. Seeking a wider role for COX-2, iNOS and eNOS besides simple stimulation of myometrial contraction reveals new relations between the major factors that regulate parturition. The purpose of this study is to examine the expression of COX-2, iNOS and eNOS mRNA levels during gestation, parturition, and postpartum in pregnant rat uterus.

\section{Materials and Methods}

Chemicals: peqGOLD TriFast ${ }^{\mathrm{TM}}$ RNA isolation kit was purchased from Peqlab (peqlab, Erlangen, Germany). Transcriptor First Strand cDNA synthesis kit, LightCycler TaqMan Master kit and RNase-free DNaseI were purchased from Roche (Roche Diagnostics, GmbH. Mannheim, Germany). All other chemicals used in this experiment were of the highest purity.

Animals and Experimental Design: Forty-two adult female Sprague Dawley rats weighing 200 - 250 g were purchased from the Laboratory Animal Breeding and Experimental Research Center of Gazi University (Ankara, Turkey). Experimental procedures were approved by Local Institutional Committee for the Ethical Use of Animals of Gazi University (protocol under number: G.Ü.ET - 08.016). The animals were maintained in individual polycarbonate cages at a constant temperature $\left(21-24^{\circ} \mathrm{C}\right)$ and humidity of $30-40 \%$ on a $12 \mathrm{~h}$ light/dark cycle. Animals were fed with standard diet and water ad libitum throughout the experiment. Stages of the estrous cycle were confirmed by vaginal smears. Also, male and female rats were mated overnight and pregnancy was confirmed by vaginal smears and/or the presence of a vaginal plug (day 1). Gestation period was similar in all groups at the beginning of this study. Rats were randomly divided into 7 groups; Group I: 10th day of gestation (10D) $(n=6)$; Group II: 15th day of gestation (15D) ( $\mathrm{n}=6)$; Group III: 18th day of gestation (18D) $(n=6)$; Group IV: 20th day of gestation (20D) (n =6); Group V, 21st day of gestation / term group (21D) $(\mathrm{n}=6)$; Group VI, first day of postpartum (PP1) $(\mathrm{n}=6)$ and Group VII, third day of postpartum (PP3) $(\mathrm{n}=6)$. Group I (10D) was considered as a control group.

Rats were sacrificed on day 10, 15, 18, 20, 21 of pregnancy, first and third days of postpartum under ketamine hydrochloride and xylazine hydrochloride anesthesia. Afterwards, both uterine horns were immediately removed, and then pups and placentas were discarded. Antimesometrial part of one uterine horn was immediately put into frozen liquid nitrogen and then stored at $-80^{\circ} \mathrm{C}$ until analysis. 
RNA Isolation and $c D N A$ Synthesis: The intrauterine tissue samples were immediately frozen in liquid nitrogen and stored at $-80{ }^{\circ} \mathrm{C}$ until the RNA isolation procedure was performed. About $100 \mathrm{mg}$ of the sample was homogenized using an IKA T10 Basic Ultra-Turrax homogenizer (IKA - Werke, Staufen, Germany). Total RNA was isolated from uterine tissues of all animals from each group by separately. Total RNA isolation from rat uterine tissues was performed by acid guanidinium thiocyanate-phenol-chloroform extraction (TRI Reagent ${ }^{\circledR}$ RT, Molecular Research Center, OH, USA) reagent in accordance with the manufacturer's instructions. The RNA - containing pellet was treated with approximately 1 - 5U RNase-free DNase per $\mu$ g RNA and incubated at $37^{\circ} \mathrm{C}$ for $30 \mathrm{~min}$ before being washed with $75 \%$ ethanol to prevent DNA contamination. After ethanol was removed, pellet was dissolved in 10 - $30 \mu$ DEPC treated water after which it was air-dried. Isolated RNA samples were kept at $-80^{\circ} \mathrm{C}$. The yield and purity of the RNA of each sample quantified by measuring absorbance at 260 and $280 \mathrm{~nm}$ using the Nanodrop spectrophotometer (NanoDrop ND-1000, Montchanin, DE, USA) and equal amounts of RNA were used for reverse transcription. cDNA was synthesized from all animals of each group separately. For each sample, $1 \mu \mathrm{g}$ of total RNA was reverse transcribed in a $20 \mu \mathrm{l}$ reaction mixture using random hexamers and Transcriptor First Strand cDNA synthesis kit (Roche Diagnostics, GmbH. Mannheim, Germany) according to the manufacturers' instructions. Reactions were performed in the PCR Sprint thermocycler (Hybaid, Heidelberg, Germany).

Quantitative Real-Time PCR (QRT-PCR) analysis: COX-2, iNOS and eNOS mRNA expression levels were measured using Real-time PCR method with the LightCycler 1.5 instrument (Roche Diagnostics, GmbH, Mannheim, Germany). Beta actin (ACTB) was used as housekeeping gene in order to normalize COX-2, iNOS and eNOS expression levels. Probes and intron spanning primers for each gene assay were designed using the Universal Probe Library (UPL) Assay Design Center (Roche Applied Science, GmbH, Mannheim, Germany). The gene-specific primer sequences and UPL numbers are provided in Table 1 . The reaction mixture prepared in borosilicate glass capillaries contained LightCycler TaqMan Master reaction mixture. Negative control experiments of each reaction were performed without the addition of template cDNA. Real-Time PCR analysis was performed from synthesis of cDNA of all animals from each group by separately. All PCR reactions were performed in the LightCycler 1.5 instrument using the following program conditions: $95^{\circ} \mathrm{C}$ for $10 \mathrm{~min}$ followed by 50 cycles at $95^{\circ} \mathrm{C}$ for $10 \mathrm{~s}$, at $60^{\circ} \mathrm{C}$ for $20 \mathrm{~s}$ and finally a cooling step to $40^{\circ} \mathrm{C}$. Each sample was tested in triplicate. Amplification efficiencies of the target genes and those of ACTB were approximately equal. Results were analyzed with LightCycler Software version 3.5 (Roche Diagnostics, GmbH. Mannheim, Germany) using the second derivate maximum method.

Statistical Analysis: All statistics were analyzed using SPSS statistical software (version 15.0 for Windows; SPSS Inc., Chicago, IL, USA). Statistical significance of differences in mRNA expressions were analyzed by pairwise fixed reallocation randomization test as statistical model included in the relative expression software tool (RESTC) developed for groupwise comparison and statistical analysis of relative expression results (32). Values of $\mathrm{P}<0.05$ were considered as significant.

\section{Results}

iNOS, eNOS, and COX-2 mRNA expression changes were investigated by QRT-PCR in the rat uterus during pregnancy, parturition and post partum. The uterine iNOS mRNA level was increased throughout pre and mid gestation and the expression of iNOS mRNA levels was highest on day 21 (21D, parturition) $(\sim 2-$ fold change, $\mathrm{P}=0.015)$. These results are summarized in Table 2 and in Fig.1. The expression of iNOS mRNA levels in the PP1 group decreased and its expression was minimal in the PP3 group compared to those in 21D group, respectively. However, this reduction was not statistically significant $(\mathrm{P}>0,05)$. These results are summarized in Table 3 and in Fig. 2.

The eNOS mRNA levels decreased significantly during pregnancy. The minimal expression level of eNOS was detected on $20 \mathrm{D}$ and $21 \mathrm{D}$ group $(\sim 2$-fold change, $\mathrm{P}=0.016, \mathrm{P}=0.014$ respectively). These results are summarized in Table 2 and in Fig. 3. The eNOS mRNA level gradually increased throughout the first and third days of postpartum when compared with the 21D group, as expected, but this increase was not statistically significant $(\mathrm{P}>0,05)$. These results are summarized in Table 3 and in Fig. 2.

Table 1. The gene - specific primer sequences and probe numbers

Tablo 1. Gene özgü primer dizileri ve prob numaraları.

\begin{tabular}{cllc}
\hline Gene & Forward Primer & Reverse Primer & UPL probe no. \\
\hline ACTB & 5' CCCGCGAGTACAACCTTCT 3' & 5' CGTCATCCATGGCGAACT 3' & 17 \\
COX - 2 & 5' ACCAACGCTGCCACAACT 3' & 5' GGTTGGAACAGCAAGGATTT 3' & 77 \\
eNOS & 5' CGGCATCACCAGGAAGAAGA 3' & 5' CATGAGCGAGGCGGAGAT 3' & 5 \\
iNOS & 5' GTGCTAATGCGGAAGGTCATG 3' & 5' GCTTCCGACTTTCCTGTCTCAGTA 3' & 128 \\
\hline
\end{tabular}


Table 2. Expression levels of COX-2, iNOS and eNOS genes in rat uterus

Tablo 2. Rat uterusunda COX-2, iNOS and eNOS genlerinin ifade düzeyleri

\begin{tabular}{|c|c|c|c|c|c|c|c|c|c|}
\hline \multirow[b]{2}{*}{ Groups } & \multicolumn{3}{|c|}{ COX-2* } & \multicolumn{3}{|c|}{ iNOS* } & \multicolumn{3}{|c|}{ eNOS* } \\
\hline & Expression & P Value & Fold Change & Expression & P Value & Fold Change & Expression & P Value & Fold Change \\
\hline 10D vs $15 D$ & 1.181 & 0.137 & 1.18 , up & 1.214 & 0.134 & 1.21 , up & 0.32 & 0.071 & 1.14, down \\
\hline $10 \mathrm{D}$ vs $18 \mathrm{D}$ & 1.273 & 0.183 & 1.27 , up & 1.459 & 0.261 & 1.45 , up & 0.28 & 0.066 & 0.97 , down \\
\hline $10 \mathrm{D}$ vs $20 \mathrm{D}$ & 1.342 & 0.201 & 1.34 , up & 1.608 & 0.357 & 1.6, up & 0.18 & $0.016^{\dagger}$ & 2.03, down \\
\hline 10D vs $21 \mathrm{D}$ & 1.651 & 0.432 & 1.65 , up & 1.93 & $0.015^{\dagger}$ & 1.93, up & 0.16 & $0.014^{\dagger}$ & 2.07 , down \\
\hline 10D vs PP1 & 0.831 & 0.154 & 1.85 , down & 0.76 & 0.169 & 1.64, down & 0.303 & 0.069 & 1.26 , up \\
\hline 10D vs PP3 & 0.448 & 0.541 & 1.41, down & 0.61 & 0.188 & 1.51, down & 0.471 & 0.086 & 1.39 , up \\
\hline
\end{tabular}

COX-2, cyclooxygenase; iNOS, inducible nitric oxide synthase; eNOS, endothelial nitric oxide synthase.

* COX-2, iNOS and eNOS mRNA expression levels normalized to ACTB and relative to 10D group using the REST

$\uparrow$ Statistically significant

COX-2, siklooksijenaz; iNOS, uyarılabilir nitrik oksit sentaz; eNOS, endotelyal nitrik oksit sentaz.

* ACTB'ya göre nomalize edilmiş ve REST kullanılarak 10D grubu ile karşılaştırılmış COX-2, iNOS ve eNOS mRNA ifade düzeyleri

$\uparrow$ İstatistiksel olarak anlamlı

Table 3. Expression levels of COX-2, iNOS and eNOS genes in rat uterus among 21D, PP1 and PP3 groups

Tablo 3. Rat uterusunda 21D, PP1 ve PP3 gruplarındaki COX-2, iNOS and eNOS genlerinin ifade düzeyleri

\begin{tabular}{|c|c|c|c|c|c|c|c|c|c|}
\hline \multirow[b]{2}{*}{ Groups } & \multicolumn{3}{|c|}{ COX-2* } & \multicolumn{3}{|c|}{ iNOS* } & \multicolumn{3}{|c|}{ eNOS* } \\
\hline & Expression & P Value & Fold Change & Expression & P Value & Fold Change & Expression & P Value & Fold Change \\
\hline 21D vs PP1 & 0.61 & 0.279 & 0.76 , down & 0.47 & 0.311 & 0.55 , down & 1.424 & 0.344 & 1.42 , up \\
\hline 21D vs PP3 & 0.49 & 0.353 & 0.53 , down & 0.35 & 0.199 & 0.73 , down & 1.671 & 0.49 & 1.67, up \\
\hline
\end{tabular}

Abbreviations as in Table 2.

* COX-2, iNOS and eNOS mRNA expression levels normalized to ACTB and relative to 21D group using the REST

$\uparrow$ Statistically significant.

Kisaltmalar Tablo 2'deki gibidir.

* ACTB'ya göre nomalize edilmiş ve REST kullanılarak 21D grubu ile karşılaştırılmış COX-2, iNOS ve eNOS mRNA ifade düzeyleri

$\uparrow$ İstatistiksel olarak anlaml

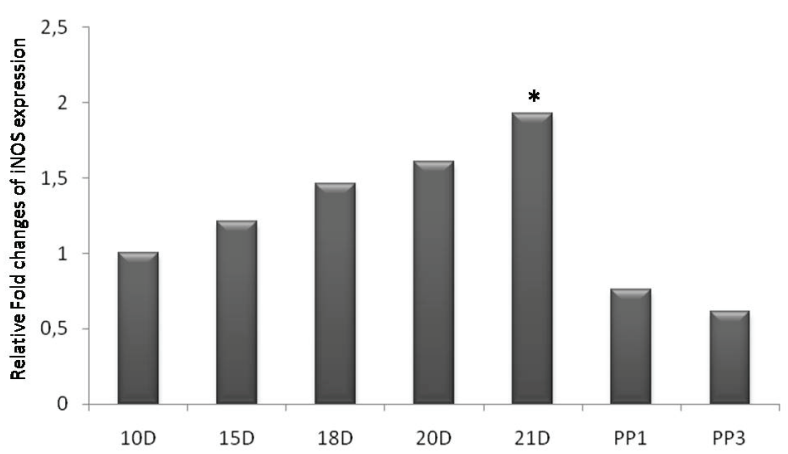

Figure 1. Relative mRNA expression level of iNOS in rat uterus tissue. Bars represent iNOS mRNA expression normalized to ACTB and relative to $10 \mathrm{D}$ group. The asterisk indicate that value was significantly different from the 10th day of gestation group $(* \mathrm{P}<0.05)$.

Şekil 1. Rat uterus dokusunda göreceli iNOS mRNA ifade düzeyi. Bar'lar ACTB' ye göre normalize edilmiş ve 10D grubu ile karşılaştırılmış iNOS mRNA ifadesini temsil eder. Yıldız işareti gebeliğin 10. gününden itibaren önemli ölçüde farklı değer olduğunu göstermektedir $(* \mathrm{P}<0.05)$.

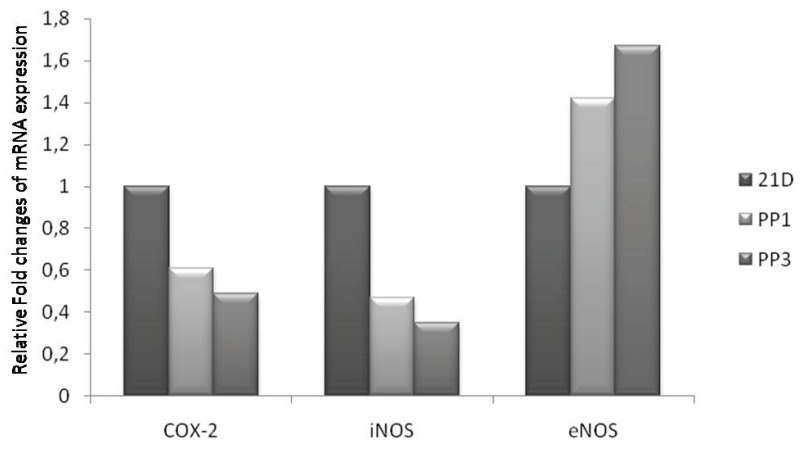

Figure 2. Relative mRNA expression levels of iNOS, eNOS and COX-2 in rat uterus among 21D, PP1 and PP3 groups. Bars represent iNOS, eNOS and COX-2 mRNA expressions normalized to $\beta$-actin and relative to $21 \mathrm{D}$ group.

Şekil 2. Rat uterusunda 21D, PP1 ve PP3 gruplarındaki göreceli iNOS, eNOS ve COX-2 mRNA ifade düzeyleri. Bar'lar ACTB' ye göre normalize edilmiş ve $21 \mathrm{D}$ grubu ile karşılaştırılmış iNOS, eNOS ve COX-2 mRNA ifadelerini temsil eder. 


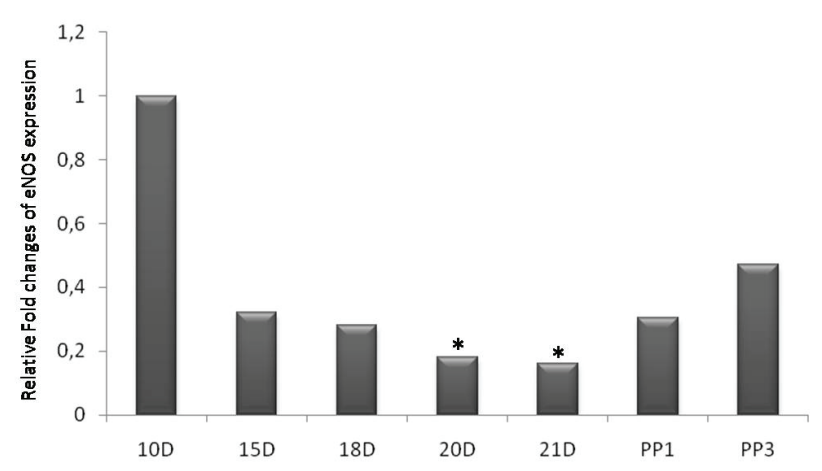

Figure 3. Relative mRNA expression level of eNOS in rat uterus tissue. Bars represent eNOS mRNA expression normalized to $\beta$-actin and relative to $10 \mathrm{D}$ group. The asterisk indicate that value was significantly different from the 10th day of gestation group $(* \mathrm{P}<0.05)$.

Şekil 3. Rat uterus dokusunda göreceli eNOS mRNA ifade düzeyi. Bar'lar ACTB' ye göre normalize edilmiş ve $10 \mathrm{D}$ grubu ile karşılaştırılmış eNOS mRNA ifadesini temsil eder. Yıldız işareti gebeliğin 10. gününden itibaren önemli ölçüde farklı değer olduğunu göstermektedir $\left({ }^{*} \mathrm{P}<0.05\right)$.

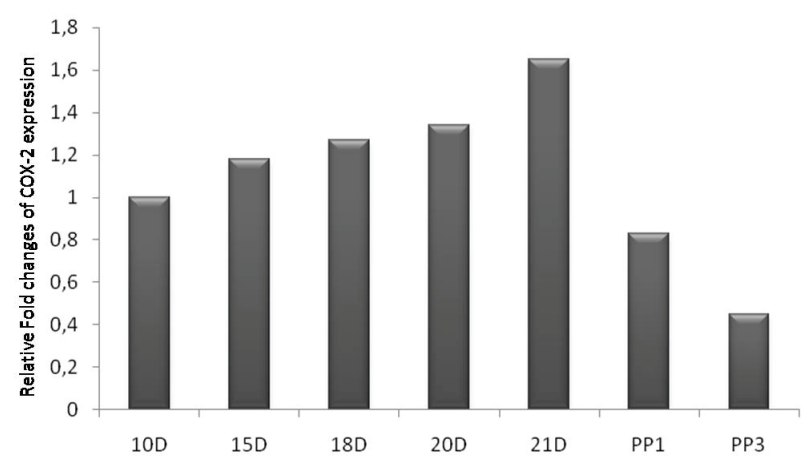

Figure 4. Relative mRNA expression level of COX-2 in rat uterus tissue. Bars represent COX-2 mRNA expression normalized to $\beta$-actin and relative to $10 \mathrm{D}$ group.

Şekil 4. Rat uterus dokusunda göreceli COX-2 mRNA ifade düzeyi. Bar'lar ACTB' ye göre normalize edilmiş ve 10D grubu ile karşılaştırılmış COX-2 mRNA ifadesini temsil eder.

The COX-2 mRNA levels were generally high in all groups, exhibiting the lowest value in the postpartum group. Uterine COX-2 mRNA levels increased through early and mid-gestation. The highest expression level of COX-2 was detected in the $21 \mathrm{D}$ group when compared to $10 \mathrm{D}$ group, although there was no statistically significant difference between the two groups $(\mathrm{P}>0,05)$. These results are summarized in Table 2 and the comparisons shown in Fig. 4. After delivery, COX-2 mRNA level fell rapidly throughout the first and third days of postpartum when compared to the $21 \mathrm{D}$ group, as expected $(\mathrm{P}>0,05)$. These results are summarized in Table 3 and the comparisons shown in Fig. 2.

\section{Discussion}

The aim of our study was to investigate the expression of COX-2 and two isoforms of NOS (iNOS and eNOS) and the relationship between the NOSs and COX-2 mRNA levels during gestation, parturition and postpartum in the rat uterus. Therefore, we designed the current study to determine whether mRNA levels for COX-2, iNOS and eNOS were differentially expressed. We also examined the relationship between COX-2, iNOS and eNOS mRNA expressions in the rat uterus.

The uterus during pregnancy is considered to be a passive organ until a contractile stimulus is given. Influences that maintain quiescence might be present throughout gestation to prevent contractions of the growing uterus (1). PGs are produced by the intrauterine tissues during pregnancy and play important roles in the regulation of uterine activity, progression of pregnancy and all of the physiological processes of parturition (1, 12, 16).

COX enzymes are major components of the PG synthesis pathway. COX-2, resulting in transcriptional activation that promote uterine contractility, is important during gestation and parturition $(6,7,22,23)$. The COX2 mRNA levels in our study appeared to be compatible with the several studies reported in literature $(3,7,31$, $15,28)$. According to our results, COX-2 mRNA levels gradually increase at the beginning of pregnancy from day 10 to 20 and expression of COX-2 was at a maximum on day 21 (parturition). Several studies have also demonstrated a dramatic increase in the inducible form of COX (COX-2) expression at both mRNA and protein levels in both preterm and term labor $(3,7,31)$. Increased COX-2 mRNA expression that occurs under term and preterm laboring conditions was shown by Marx et al (15). In addition, Arslan and Zingg showed that COX-2 mRNA levels were increased in the uterus from the seventh day of rat pregnancy until parturition (3). Moreover, Dong et al. showed increased protein levels of COX-2 in laboring rat uterine tissue (7). Interestingly, $\mathrm{Wu}$ et al. also found an increase in COX-2 mRNA and protein expression in ovine endometrium, myometrium, and placenta during labor (28). Thus, similar mechanisms could be involved in the regulation of uterus regression in the rat endometrium during gestation.

Identification of eNOS and iNOS in human endometrium suggests that NOS may be involved in the local control of uterine function (2). iNOS is present in the cervix of many different species during pregnancy and increases during labour, suggesting a role for NO in the ripening process and parturition $(2,14)$. Furthermore, during pregnancy in both rats and humans, endometrium expresses the enzyme iNOS which is a smooth muscle relaxant $(4,19)$. Buhimschi et al. investigated the presence and gestational differences in NOS isoforms in the rat uterus versus the cervix and concluded that only iNOS and eNOS were present in the uterus during pregnancy (5). In the present study, we also found a 
significant increase of iNOS mRNA levels at the beginning of pregnancy from day 10 to 20 and iNOS expression is maximal at parturition (day 21). In contrast, eNOS mRNA levels decreased during gestation and increased on the first and third days of postpartum. However, there was no statistically significant alteration in eNOS mRNA levels among groups. Consistent with our study, Fittkow et al. compared the gestation, parturition and postpartum tissues and they showed that iNOS expression was gradually increased in guinea pigs during pregnancy (9). Furthermore, Dong et al demonstrated that iNOS mRNA expression in the rat uterus was substantially increased during pregnancy and decreased during labor, consistent with the changes in uterine NO production and NOS protein. eNOS expression was present at all stages examined, but the concentrations were unchanged. Therefore, regulation of iNOS at the mRNA level might play a role in modulating uterine activity during pregnancy (8). Tschugguel et al. have also suggested that iNOS mRNA expression was higher in the cervical tissues of women in the postpartum period compared with the non-pregnant state. In contrast, no alteration in the expression of eNOS was observed (27). In the present study, we found that uterine iNOS mRNA expression increases during pregnancy and decreases during labor and postpartum. These data suggest that an increase in iNOS gene expression in the uterus may be important in the maintenance of pregnancy and a decrease of iNOS mRNA in the uterus at term may be involved in the initiation of parturition. Thus, the NO system may inhibit uterine contractility during pregnancy to maintain uterine quiescence.

NO is interacted with PG pathways in regulating the NOS and COX expression. This interaction may play a critical role in the control of cervical ripening and parturition $(2,6,26)$. Our data showed the expression of the iNOS, eNOS and COX-2, which have been suggested as mediators of formation of during gestation, parturition and postpartum in pregnant rat uterine. At term, under normal laboring conditions, eNOS mRNA levels decreased, whereas iNOS and COX-2 levels increased. A potential interaction between iNOS and COX-2 at the protein and product level has also been reported. Studies show that iNOS and COX-2 enzymes were co-localized during gestation under normal conditions $(25,30)$. Marx et al also demonstrated the relationship between COX-2 and iNOS in the control of cervical ripening and parturition under both term and preterm laboring conditions (15). Moreover, recent studies reported that iNOS mRNA levels had a tendency to decrease whereas COX-2 mRNA levels increased as pregnancy progressed to term, demonstrating an inverse relationship $(7,8,24)$. Our data support these studies suggesting that there may be a possible interaction between the $\mathrm{NO}$ and $\mathrm{PG}$ pathways in regulating the iNOS and COX-2 expression and this interaction may play a critical role in the control of cervical ripening and parturition $(8,10,24,25,30)$. On the basis of these studies as models for NOS and PG interactions, it can be hypothesized that $\mathrm{NO}$ is uniquely involved in the maintenance of uterine relaxation during pregnancy and in the initiation of labor. NOS isoforms have been found to enhance the COX-2 enzyme activity which thereby up-regulates the PG synthesis. Also, these data propound the existence of a relationship between iNOS and COX-2 in regulating the mRNA expression in gestation and parturition.

In conclusion, these results characterize the expression of COX-2, iNOS and eNOS in the pregnant rat uterus. Our study shows that mRNA levels for iNOS, eNOS and COX-2 changes in the rat uterus during pregnancy, parturition and postpartum. We determined significantly high levels of iNOS and COX-2 and low eNOS mRNA levels in the rat uterus during pregnancy and parturition. These results are consistent with the hypothesis suggesting that $\mathrm{NO}$ and $\mathrm{PG}$ production in the uterus during pregnancy is elevated to assist suppressing uterine contractility and maintaining uterine quiescence while its withdrawal prior to birth might play an important role in initiating term labor.

\section{Acknowledgments}

This study was supported by Gazi University Research Fund as a project and assigned the project code number 01/2008-33.

\section{Disclaimer}

This study was presented in the form of a poster to "The EMBO Meeting 2010", held on 4-7 September 2010 in Barcelona-SPAIN.

\section{References}

1- Abel MH, Kelly RW (1979): Differential production of prostaglandins within the human uterus. Prostaglandins, 18, 821-828.

2- Ali M, Buhimschi I, Chwalisz K, Garfield RE (1997): Changes in expression of the nitric oxide synthase isoforms in rat uterus and cervix during pregnancy and parturition. Mol Hum Reprod, 3, 995-1003.

3- Arslan A, Zingg HH (1996): Regulation of COX-2 gene expression in rat uterus in vivo and in vitro. Prostaglandins, 52, 463-481.

4- Bansal RK, Goldsmith PC, He Y, Zaloudek CJ, Ecker JL, Riemer RK (1997): A decline in myometrial nitric oxide synthase expression is associated with labor and delivery. J Clin Invest, 99, 2502-2508.

5- Buhimschi I, Ali M, Jain V, Chwalisz K, Garfield RE (1996): Differential regulation of nitric oxide in the rat uterus and cervix during pregnancy and labour. Hum Reprod, 11, 1755-1766.

6- Chwalisz K, Garfield RE (1997): Regulation of the uterus and cervix during pregnancy and labor. Role of 
progesterone and nitric oxide. Ann N Y Acad Sci, 828, 238-53.

7- Dong YL, Gangula PR, Fang L, Yallampalli C (1996): Differential expression of cyclooxygenase-1 and -2 proteins in rat uterus and cervix during the estrous cycle, pregnancy, labor and in myometrial cells. Prostaglandins, 52, 13-34.

8- Dong YL, Gangula PRR, Yallampalli C (1996): Nitric oxide synthase isoforms in the rat uterus: differential regulation during pregnancy and labor. J Reprod Fertil, 107, 249-254.

9- Fittkow CT, Shi SQ, Bytautiene E, Olson G, Saade GR, Garfield RE (2001): Changes in light-induced fluorescence of cervical collagen in guinea pigs during gestation and after sodium nitroprusside treatment. J Perinat Med, 29, 535-543.

10- Ghabour MS, Eis AL, Brockman DE, Pollock JS, Myatt L (1995): Immunohistochemical characterization of placental nitric oxide synthase expression in preeclampsia. Am J Obstet Gynecol, 173, 687-694.

11- Gibb W (1998): The role of prostaglandins in human parturition. Ann Med, 30, 235-241.

12- Keirse MJ (1993): Prostaglandins in preinduction cervical ripening. Meta-analysis of worldwide clinical experience. J Reprod Med, 38, 89-100.

13- Knowles RG, Moncada S (1994): Nitric oxide synthases in mammals. Biochem J, 298, 249-258.

14- Ledingham MA, Thomson AJ, Young A, Macara LM, Greer IA, Norman JE (2000): Changes in the expression of nitric oxide synthase in the human uterine cervix during pregnancy and parturition. Mol Hum Reprod, 6, 10411048.

15- Marx SG, Wentz MJ, Mackay LB, Schlembach D, Maul H, Fittkow C, Given R, Vedernikov Y, Saade GR, Garfield RE (2006): Effects of progesterone on iNOS, $\mathrm{COX}-2$, and collagen expression in the cervix. J Histochem Cytochem, 54, 623-639.

16- Mitchell MD, Romero RJ, Edwin SS, Trautman MS (1995): Prostaglandins and parturition. Reprod Fertil Dev, 7, 623-632.

17- Moncada SR, Palmer MG, Higgs EA (1995): Nitric oxide: physiology, pathophysiology and pharmacology. Pharmacol Rev, 43, 109-142.

18- Natuzzi ES, Ursell PC, Harrison M, Buscher C, Riemer RK (1993): Nitric oxide synthase activity in the pregnant uterus decreases at parturition. Biochem Biophys Res Commun, 194, 1-8.

19- Okawa T, Asano K, Takahashi H, Hashimoto S, Anbe H, Sato A, Vedernikov YP, Saade GR, Garfield RE (2004): Expression of inducible nitric oxide synthase messenger RNA, but not guanylate cyclase messenger $R N A$, depends on gestational age in rat myometrium. Gynecol Endocrinol, 19, 146-151.

20- Olson DM, Mijovic JE, Sadowsky DW (1995): Control of human parturition. Semin Perinatol, 19, 52-63.

21- Sladek SM, Regenstein AC, Lykins D, Roberts JM (1993): Nitric oxide synthase activity in pregnant rabbit uterus decreases on the last day of pregnancy. Am J Obstet Gynecol, 169, 1285-1291.
22- Smith WL, DeWitt DL (1996): Prostaglandin endoperoxide H synthases-1 and -2. Adv Immunol, 62, 167-215.

23- Smith WL, Garavito RM, DeWitt DL (1996): Prostaglandin endoperoxide $H$ synthases (cyclooxygenases)-1 and -2. J Biol Chem, 271, 3315733160 .

24- Swaisgood CM, Zu HX, Perkins DJ, Wu S, Garver CL, Zimmerman PD, Iams JD, Kniss DA (1997): Coordinate expression of inducible nitric oxide synthase and cyclooxygenase-2 genes in uterine tissues of endotoxintreated pregnant mice. Am J Obstet Gynecol, 177, 12531262.

25- Tetsuka T, Daphna-Iken D, Srivastava SK, Baier LD, DuMaine J, Morrison AR (1994): Cross-talk between cyclooxygenase and nitric oxide pathways: prostaglandin E2 negatively modulates induction of nitric oxide synthase by interleukin 1. Proc Natl Acad Sci USA, 91, 1216812172.

26- Thomson AJ, Telfer JF, Kohnen G, Young A, Cameron IT, Greer IA, Norman JE (1997): Nitric oxide synthase activity and localization do not change in uterus and placenta during human parturition. Hum Reprod, 12, 2546-2552.

27- Tschugguel W, Schneeberger C, Lass H, Stonek F, Zaghlula MB, Czerwenka K, Schatten C, Kaider A, Husslein P, Huber JC (1999): Human cervical ripening is associated with an increase in cervical inducible nitric oxide synthase expression. Biol Reprod, 60, 1367-1372.

28- Wu WX, Ma XH, Nathanielsz PW (1999): Tissuespecific ontogenic expression of prostaglandin $H$ synthase 2 in the ovine myometrium, endometrium, and placenta during late gestation and at spontaneous term labor. Am J Obstet Gynecol, 181, 1512-1519.

29- Yang ZM, Das SK, Wang J, Sugimoto Y, Ichikawa A, Dey SK (1997): Potential sites of prostaglandin actions in the periimplantation mouse uterus: differential expression and regulation of prostaglandin receptor genes. Biology of Reproduction, 56, 368-379.

30- Zhang H, Chen X, Teng X, Snead C, Catravas JD (1998): Molecular cloning and analysis of the rat inducible nitric oxide synthase gene promoter in aortic smooth muscle cells. Biochem Pharmacol, 55, 1873-1880.

31- Zuo J, Lei ZM, Rao CV, Pietrantoni M, Cook VD (1994): Differential cyclooxygenase-1 and -2 gene expression in human myometria from preterm and term deliveries. J Clin Endocrinol Metab, 79, 894-899.

32- Pfaffl MW, Horgan GW, Dempfle L (2002): Relative expression software tool (REST) for group-wise comparison and statistical analysis of relative expression results in real-time PCR. Nucleic Acids Res, 30, 36.

Geliş tarihi: 08.08.2011 / Kabul tarihi: 29.03.2012

Address for correspondence:

MsC. Atiye Seda Yar

Gazi University, Faculty of Medicine,

Department of Medical Biology and Genetics, 06500, Besevler/Ankara/Turkey

e-mail: atiyeseda@yahoo.com 